\title{
FAKTOR RISIKO STUNTING PADA BALITA (24-59 BULAN) DI SUMATERA
}

\author{
(Risk Factors of Stunting among Children [24-59 months] in Sumatera)
}

\author{
Zilda Oktarina ${ }^{1}$ dan Trini Sudiarti ${ }^{1 *}$
}

'Departemen Gizi Kesehatan Masyarakat, Fakultas Kesehatan Masyarakat, Universitas Indonesia, Depok

\begin{abstract}
This study was aimed to analyze risk factors of stunting in underfive children aged 24-59 months in Sumatera. A cross sectional study was conducted in 1239 children at Aceh, North Sumatera, South Sumatera, and Lampung Provinces who have complete variable data of the National Basic Health Research 2010. The data were collected by questionnaires and anthropometric assessment. Chi square analysis and logistic regression were used to assess the association between risk factors and stunting in children. The result showed that prevalence of stunting among children were $44.1 \%$. The significant risk factors of stunting among subjects $(p<0.05)$ were mother's height $(O R=1.36)$, fat intake $(O R=1.30)$, family size $(O R=1.38)$, and drinking water resources $(O R=1.36)$. The dominant factor that associated with stunting in children was family size $(O R=1.38)$. Researcher suggest that family can control total children with family planning program.
\end{abstract}

Keywords: family size, stunting, underfive children

\begin{abstract}
ABSTRAK
Penelitian bertujuan untuk menganalisis faktor risiko stunting pada balita usia 24-59 bulan di Sumatera. Desain penelitian yang digunakan adalah cross sectional yang melibatkan subjek 1239 balita di Provinsi Aceh, Sumatera Utara, Sumatera Selatan, dan Lampung yang memiliki kelengkapan data variabel penelitian. Data diambil dari hasil Riskesdas 2010. Pengumpulan data Riskesdas 2010 menggunakan kuesioner dan pengukuran antropometri. Analisis chi square dan regresi logistik digunakan untuk mengetahui hubungan antara faktor risiko dengan kejadian stunting pada balita. Hasil penelitian menunjukkan prevalensi balita stunting 44.1\%. Faktor risiko stunting pada balita $(\mathrm{p}<0.05)$ yaitu tinggi badan ibu $(\mathrm{OR}=1.36)$, tingkat asupan lemak $(\mathrm{OR}=1.30)$, jumlah anggota rumah tangga $(\mathrm{OR}=1.38)$ dan sumber air minum $(\mathrm{OR}=1.36)$. Faktor dominan yang berhubungan dengan kejadian stunting pada balita adalah jumlah anggota rumah tangga. Keluarga disarankan agar dapat membatasi jumlah anak sesuai dengan program Keluarga Berencana (KB).
\end{abstract}

Kata kunci: balita, besar keluarga, stunting

"Korespondensi: Departemen Gizi Kesehatan Masyarakat, Fakultas Kesehatan Masyarakat, Universitas Indonesia, Kampus UI Depok. Email: trini@ui.ac.id 


\section{PENDAHULUAN}

Stunting merupakan salah satu permasalahan gizi yang terjadi di Indonesia. Dampak stunting tidak hanya dirasakan oleh individu yang mengalaminya, tetapi juga berdampak terhadap roda perekonomian dan pembangunan bangsa. Hal ini karena sumber daya manusia stunting memiliki kualitas lebih rendah dibandingkan dengan sumber daya manusia normal.

Beberapa penelitian menunjukkan bahwa anak yang pada masa balitanya mengalami stunting memiliki tingkat kognitif rendah, prestasi belajar dan psikososial buruk (Achadi 2012). Anak yang mengalami severe stunting di dua tahun pertama kehidupannya memiliki hubungan sangat kuat terhadap keterlambatan kognitif di masa kanak-kanak nantinya dan berdampak jangka panjang terhadap mutu sumberdaya (Brinkman et al. 2010; Martorell et al. 2010). Kejadian stunting yang berlangsung sejak masa kanak-kanak memiliki hubungan terhadap perkembangan motorik lambat dan tingkat intelegensi lebih rendah (Martorell et al. 2010). Penelitian lain menunjukkan anak (9-24 bulan) yang stunting selain memiliki tingkat intelegensi lebih rendah, juga memiliki penilaian lebih rendah pada lokomotor, koordinasi tangan dan mata, pendengaran, berbicara, maupun kinerja jika dibandingkan dengan anak normal (Chang et al. 2010).

Tingkat kognitif rendah dan gangguan pertumbuhan pada balita stunting merupakan faktor-faktor yang dapat menyebabkan kehilangan produktivitas pada saat dewasa. Orang dewasa stunting memiliki tingkat produktivitas kerja rendah serta upah kerja lebih rendah bila dibandingkan dengan orang dewasa yang tidak stunting (Hunt 2005).

Anak-anak yang mengalami stunting pada dua tahun kehidupan pertama dan mengalami kenaikan berat badan yang cepat, berisiko tinggi terhadap penyakit kronis, seperti obesitas, hipertensi, dan diabetes (Victora et al. 2008). Retardasi pertumbuhan postnatal memiliki potensi hubungan terhadap berat badan sekarang dan tekanan darah. Menurut Barker (2008) tekanan darah pada orang dewasa memiliki hubungan negatif terhadap berat lahir dan tekanan darah pada masa kanak-kanak memiliki hubungan terhadap ukuran bayi pada saat dilahirkan.

Kejadian stunting pada balita merupakan salah satu permasalahan gizi secara global. Berdasarkan data UNICEF 2000-2007 menunjukkan prevalensi kejadian stunting di dunia mencapai $28 \%$, di Afrika bagian timur dan selatan sebesar $40 \%$, dan di Asia Selatan sebesar 38\%. Bila dibandingkan dengan batas "non public health problem" menurut WHO untuk masalah stunting sebesar $20 \%$, maka hampir seluruh negara di dunia mengalami masalah kesehatan masyarakat. Kejadian stunting pada balita lebih banyak terjadi di negara berkembang. Hal ini dibuktikan dengan prevalensi kejadian stunting pada balita di negara berkembang sebesar 30\% (UNICEF Report 2009). Indonesia merupakan salah satu negara berkembang yang memiliki kejadian stunting pada balita tinggi. Empat provinsi di Pulau Sumatera memiliki angka kejadian stunting pada balita tinggi yaitu Provinsi Aceh (39.0\%), Sumatera Utara (42.3\%), Sumatera Selatan (40.4\%), dan Lampung (36.2\%). Angka prevalensi tersebut dapat dinyatakan tinggi jika dibandingkan dengan prevalensi kejadian rata-rata stunting pada balita secara nasional yaitu 35.6\%. (Balitbangkes 2010).

Penelitian terdahulu menyimpulkan faktor yang berhubungan dengan stunting antara lain berat lahir (Varela et al. 2009), postur tubuh ibu pendek (Yang et al. 2010), asupan energi, protein, lemak (Assis et al. 2004), status ekonomi keluarga (Hong 2007), jumlah anggota rumah tangga (Tshwane University 2006) dan fasilitas air (Merchant 2003). Sehubungan dengan hal tersebut perlu dikaji tentang faktor-faktor risiko stunting pada balita yaitu berat lahir, tinggi badan ibu, tingkat asupan (energi, protein, lemak), status ekonomi keluarga, jumlah anggota keluarga, dan sumber air minum.

Tujuan penelitian untuk mengetahui gambaran kejadian stunting pada balita di empat provinsi tersebut dan hubungannya dengan faktor-faktor risiko seperti berat lahir, tinggi badan ibu, tingkat asupan energi, tingkat asupan protein, tingkat asupan lemak, status ekonomi keluarga, jumlah anggota rumah tangga, dan sumber air minum serta menganalisis faktor risiko yang berhubungan dengan kejadian stunting pada balita di empat provinsi tersebut.

\section{METODE}

\section{Desain, Tempat, dan Waktu Penelitian}

Desain penelitian yang digunakan adalah cross sectional dengan pendekatan kuantitatif. Penelitian menggunakan data sekunder berasal dari Riset Kesehatan Dasar (Riskesdas) tahun 2010. Tempat penelitian terpilih adalah Provinsi Aceh, Sumatera Utara, Sumatera Selatan, dan Lampung, meliputi seluruh kabupaten/kota yang ada. Kabupaten/kota pemekaran yang belum tercantum dalam laporan subjek terpilih digabungkan dengan kabupaten/kota induknya. Waktu penelitian pada bulan Maret sampai Mei 2012.

\section{Jumlah dan Cara Pengambilan Subjek}

Populasi penelitian adalah semua balita usia 24-59 bulan yang terdapat pada data Riskesdas 2010 di wilayah Provinsi Aceh, Sumatera Utara, Sumatera Selatan, dan Lampung. Subjek penelitian meliputi seluruh balita usia 24-59 bulan yang digunakan oleh empat propinsi tersebut dan mempunyai data lengkap sesuai dengan variabel penelitian. Terdapat 
1239 balita yang memiliki kelengkapan data meliputi tinggi badan, umur, jenis kelamin, berat lahir, tinggi badan ibu balita, jumlah asupan energi, protein, lemak, status ekonomi keluarga, jumlah anggota rumah tangga, dan sumber air minum.

Hasil perhitungan kekuatan uji untuk variabel berat lahir, tinggi badan ibu, tingkat asupan energi, tingkat asupan protein, tingkat asupan lemak, status ekonomi keluarga, jumlah anggota rumah tangga dan sumber air minum memiliki nilai lebih besar atau sama dengan $80 \%$.

\section{Jenis dan Cara Pengumpulan Data}

Variabel dependen dalam penelitian ini adalah kejadian stunting pada balita usia 24-59 bulan, sedangkan variabel independen adalah berat lahir, tinggi badan ibu, tingkat asupan energi, tingkat asupan protein, tingkat asupan lemak, status ekonomi keluarga, jumlah anggota rumah tangga, dan sumber air minum.

Data sekunder diperoleh dari Badan Penelitian dan Pengembangan Kesehatan Kementrian Kesehatan RI. Pengumpulan data dilakukan oleh Tim Riskesdas 2010 dari Balitbangkes, Kementrian Kesehatan pada bulan Mei-Agustus 2010. Data karakteristik demografi dan sosial ekonomi diperoleh melalui wawancara menggunakan kuesioner. Data konsumsi pangan diperoleh dengan metode recall 1x24 jam. Pengukuran tinggi badan menggunakan alat ukur tinggi badan "Multi fungsi" dengan kapasitas ukur dua meter dan ketelitian $0.1 \mathrm{~cm}$.

\section{Pengolahan dan Analisis Data}

Analisis data meliputi univariat, bivariat, dan multivariat. Analisis univariat digunakan untuk menggambarkan kejadian stunting pada balita, berat lahir, tinggi badan ibu, tingkat asupan energi, tingkat asupan protein, tingkat asupan lemak, status ekonomi keluarga, jumlah anggota rumah tangga, dan sumber air minum. Analisis bivariat yang digunakan adalah uji chi-square untuk melihat hubungan kejadian stunting pada balita dengan berat lahir, tinggi badan ibu, tingkat asupan energi, tingkat asupan protein, tingkat asupan lemak, status ekonomi keluarga, jumlah anggota rumah tangga, dan sumber air minum. Analisis regresi logistik ganda digunakan untuk mengetahui faktor risiko kejadian stunting pada balita.

\section{HASIL DAN PEMBAHASAN}

\section{Karakteristik Balita dan Rumah Tangga}

Sebaran karakteristik balita dan rumah tangga menunjukkan bahwa sebesar 24.2\% balita di empat provinsi mengalami severe stunting dan $19.9 \%$ moderate stunting. Prevalensi stunting ini lebih tinggi jika dibandingkan dengan angka nasional Riskesdas 2010 yaitu $35.6 \%$. Hal ini menandakan bahwa di dae- rah-daerah tersebut hampir setengah jumlah balita mengalami stunting. Hasil penelitian juga menunjukkan prevalensi balita memiliki berat lahir kurang sebesar 27.8\%. Sebanyak 59.3\% ibu-ibu balita memiliki tinggi badan tergolong pendek; balita memiliki tingkat asupan energi, protein, dan lemak yang rendah berturut-turut sebesar 48.3\%,12.4\%, 48.5\%; $65.1 \%$ keluarga balita tergolong status ekonomi rendah; 49.7\% keluarga balita tergolong keluarga yang memiliki jumlah anggota rumah tangga banyak; dan 30.3\% balita berasal dari lingkungan dengan sumber air tidak terlindung.

\section{Hubungan berbagai Variabel}

Tabel 1 menunjukkan bahwa kejadian stunting pada balita memiliki hubungan dengan berat lahir $(p=0.03$; OR=1.31), tinggi badan ibu $(p=0.01$; $\mathrm{OR}=1.36$, tingkat asupan energi $(\mathrm{p}=0.03$; $\mathrm{OR}=1.28)$, tingkat asupan lemak $(p=0.02 ; O R=1.31)$, status ekonomi keluarga $(p=0.03 ; O R=1.29)$, jumlah anggota rumah tangga $(p=0.01 ; O R=1.34)$, dan sumber air minum $(p=0.01 ; O R=1.35)$.

Pada penelitian ini ditemukan hubungan antara berat lahir dengan kejadian stunting pada balita. Balita yang memiliki berat lahir kurang mempunyai risiko 1.31 kali mengalami stunting dibandingkan dengan balita berat lahir normal. Hal ini sejalan dengan hasil penelitian Varela et al. 2009. Penelitian di Pulau Sulawesi juga menunjukkan bahwa anak dengan berat lahir kurang dari 3000 g memiliki risiko menjadi stunting 1.3 kali dibandingkan anak dengan berat lahir lebih dari atau sama dengan 3000 g (Simanjuntak 2011). Berat lahir merupakan prediktor kuat terhadap penentuan ukuran tubuh di kemudian hari. Hal ini karena pada umumnya bayi yang mengalami Intra Uterine Growth Retardation (IUGR) tidak dapat mengejar pertumbuhan ke bentuk normal selama masa kanak-kanak (Barker 2008). Berdasarkan hasil penelitian ditemukan hubungan antara tinggi badan ibu dengan kejadian stunting pada balita. Ibu yang memiliki tinggi badan pendek mempunyai risiko 1.36 kali memiliki balita stunting dibandingkan dengan ibu yang memiliki tinggi badan normal. Hal ini sejalan dengan penelitian di Cina yang menunjukkan adanya hubungan antara tinggi badan ibu dengan kejadian stunting. Tinggi badan ibu <155 cm lebih berisiko memiliki anak stunting (Yang et al. 2010). Postur tubuh ibu juga mencerminkan tinggi badan ibu dan lingkungan awal yang akan memberikan kontribusi terhadap tinggi badan anak sebagai faktor independen. Namun demikian, masih banyak faktor lingkungan yang memengaruhi tinggi badan anak (Taguri et al. 2008).

Terdapat hubungan antara tingkat asupan energi dengan kejadian stunting pada balita. Balita yang memiliki asupan energi rendah mempunyai risiko 1.28 kali mengalami stunting dibandingkan dengan balita yang memiliki tingkat asupan energi 
Tabel 1. Hubungan berbagai Variabel dengan Status Gizi

\begin{tabular}{|c|c|c|c|c|c|c|}
\hline \multirow{2}{*}{ Variabel } & \multicolumn{2}{|c|}{ Stunting } & \multicolumn{2}{|c|}{ Normal } & \multirow{2}{*}{ OR 95 \% Cl } & \multirow{2}{*}{$p$ value } \\
\hline & $\mathrm{n}$ & $\%$ & $\mathrm{n}$ & $\%$ & & \\
\hline \multicolumn{7}{|l|}{ Berat Lahir: } \\
\hline Kurang & 169 & 49.0 & 178 & 51.0 & 1.31 & \multirow{2}{*}{0.03} \\
\hline Normal & 378 & 42.3 & 516 & 57.7 & $(1.02-1.68)$ & \\
\hline \multicolumn{7}{|l|}{ Tinggi Badan Ibu: } \\
\hline Pendek & 347 & 47.2 & 388 & 53.3 & 1.36 & \multirow{2}{*}{0.01} \\
\hline Normal & 200 & 39.7 & 304 & 60.3 & $(1.08-1.70)$ & \\
\hline \multicolumn{7}{|c|}{ Tingkat Asupan Energi: } \\
\hline Rendah & 283 & 47.2 & 316 & 52.8 & 1.28 & \multirow{2}{*}{0.03} \\
\hline Cukup & 264 & 41.3 & 376 & 58.7 & $(1.01-1.59)$ & \\
\hline \multicolumn{7}{|c|}{ Tingkat Asupan Protein: } \\
\hline Rendah & 58 & 37.7 & 96 & 62.3 & - & \multirow{2}{*}{0.09} \\
\hline Cukup & 489 & 45.1 & 596 & 54.9 & & \\
\hline \multicolumn{7}{|c|}{ Tingkat Asupan Lemak: } \\
\hline Rendah & 286 & 47.6 & 315 & 52.4 & 1.31 & \multirow{2}{*}{0.02} \\
\hline Cukup & 261 & 40.9 & 377 & 59.1 & $(1.05-1.64)$ & \\
\hline \multicolumn{7}{|c|}{ Status Ekonomi Keluarga: } \\
\hline Rendah & 374 & 46.3 & 434 & 53.7 & 1.29 & \multirow{2}{*}{0.03} \\
\hline Tinggi & 173 & 40.0 & 258 & 60.0 & $(1.02-1.64)$ & \\
\hline \multicolumn{7}{|c|}{ Jumlah Anggota Rumah Tangga: } \\
\hline Banyak & 294 & 47.7 & 322 & 52.3 & 1.34 & \multirow{2}{*}{0.01} \\
\hline Cukup & 253 & 40.6 & 370 & 59.4 & $(1.06-1.67)$ & \\
\hline \multicolumn{7}{|l|}{ Sumber Air Minum: } \\
\hline Tidak Terlindung & 185 & 49.3 & 190 & 50.7 & 1.35 & \multirow{2}{*}{0.01} \\
\hline Terlindung & 362 & 41.9 & 502 & 58.1 & $(1.05-1.72)$ & \\
\hline
\end{tabular}

cukup. Hal ini sesuai kerangka teori UNICEF yang menyatakan konsumsi makanan tidak adekuat merupakan salah satu faktor yang dapat mengakibatkan stunting (UNICEF 1998). Sebuah studi yang dilakukan oleh Xiaoli et al.(2009) juga menunjukkan bahwa penyebab kejadian stunting di Cina adalah defisiensi energi dan protein yang telah berlangsung jangka panjang.

Temuan studi menunjukkan sebagian besar balita memiliki tingkat asupan protein cukup, namun secara statistik tidak ditemukan hubungan antara tingkat asupan protein dengan kejadian stunting pada balita. Beberapa alasan tidak ditemukan hubungan tersebut diduga disebabkan oleh beberapa faktor. Kejadian stunting merupakan peristiwa yang terjadi dalam periode waktu lama, sehingga tingkat asupan protein yang terjadi sekarang tidak menjadi salah satu penyebab kejadian stunting. Asupan protein bukan merupakan satu-satunya faktor yang memengaruhi kejadian stunting. Faktor-faktor lain yang menyebabkan anak menjadi stunting selain kurang asupan protein adalah defisiensi zat gizi mikro, zat gizi dalam kandungan, ukuran tubuh ibu, dan infeksi (Lee et al. 2010).
Hasil studi menunjukkan bahwa proporsi balita dengan tingkat asupan lemak yang rendah mengalami stunting lebih banyak dibandingkan proporsi balita dengan asupan lemak cukup. Secara statistik, hasil penelitian menunjukkan terdapat hubungan antara asupan lemak dengan kejadian stunting pada balita. Balita dengan tingkat asupan lemak rendah 1.31 kali lebih berisiko mengalami stunting dibandingkan balita dengan tingkat asupan lemak cukup. Hal ini sesuai dengan hasil survei di Cina tahun 2006 yang menunjukkan kejadian stunting pada anak usia kurang dari lima tahun dikaitkan dengan asupan energi, protein, dan lemak (Xiaoli et al. 2009).

Balita yang berasal dari keluarga dengan status ekonomi rendah lebih banyak mengalami stunting dibandingkan balita dari keluarga dengan status ekonomi tinggi. Secara statistik hasil penelitian ini menunjukkan bahwa terdapat hubungan antara status ekonomi keluarga dengan kejadian stunting pada balita. Balita yang berasal dari keluarga dengan status ekonomi rendah 1.29 kali berisiko mengalami stunting dibandingkan dengan balita dari keluarga dengan status ekonomi tinggi. Temuan ini sesuai dengan hasil penelitian sebelumnya yang 
menyebutkan ada hubungan antara status ekonomi keluarga dengan kejadian stunting pada balita. Status ekonomi keluarga memiliki hubungan yang kuat terhadap kejadian stunting (Hong 2007). Status ekonomi keluarga yang lebih rendah cenderung memiliki anak stunting (Lee et al. 2010).

Balita dari keluarga dengan jumlah anggota rumah tangga banyak cenderung mengalami stunting dibandingkan balita dari keluarga dengan jumlah anggota rumah tangga cukup. Dapat disimpulkan bahwa terdapat hubungan antara jumlah anggota rumah tangga dengan kejadian stunting pada balita. Balita dari keluarga dengan jumlah anggota rumah tangga banyak lebih berisiko 1.34 kali mengalami stunting dibandingkan dengan balita dari keluarga dengan jumlah anggota rumah tangga cukup. Hasil penelitian ini sejalan dengan penelitian sebelumnya yang menunjukkan jumlah anggota rumah tangga memiliki hubungan signifikan terhadap kejadian stunting pada balita. Tshwane University (2006) dalam penelitiannya juga menemukan adanya hubungan besar keluarga dengan kejadian stunting pada balita. Anak-anak stunting berasal dari keluarga yang memiliki jumlah anggota rumah tangga lebih banyak dibandingkan dengan anak-anak normal.

Temuan lain studi ini menunjukkan bahwa balita dari keluarga yang memiliki sumber air minum tidak terlindung lebih banyak mengalami stunting dibandingkan balita dari keluarga yang memiliki sumber air minum terlindung. Studi membuktikan bahwa terdapat hubungan antara sumber air minum dengan kejadian stunting balita. Balita yang berasal dari keluarga yang memiliki sumber air minum tidak terlindung 1.35 kali lebih berisiko mengalami stunting dibandingkan dengan balita dari keluarga dengan sumber air minum terlindung. Sumber air minum yang bersih merupakan faktor penting untuk kesehatan tubuh dan mengurangi risiko serangan berbagai penyakit seperti diare, kolera, dan tipes. Anak-anak merupakan subjek yang rentan terhadap penyakit infeksi karena secara alami kekebalan anak tergolong rendah. Kematian dan kesakitan pada anak-anak umumnya dikaitkan dengan sumber air minum yang tercemar dan sanitasi yang tidak memadai. Beberapa penelitian di berbagai negara menunjukkan bahwa kualitas sumber air minum memiliki hubungan positif dengan pengurangan kejadian diare dan kematian pada anak (Adewara et al. 2011).

Hasil uji regresi logistik ganda seperti terlihat pada Tabel 2 menunjukkan bahwa jumlah anggota rumah tangga merupakan faktor dominan yang berhubungan dengan kejadian stunting pada balita. Di antara faktor sosiodemografi faktor yang paling berisiko tinggi terhadap kejadian stunting adalah besarnya keluarga. Hal ini karena keluarga butuh kemampuan lebih agar dapat menyediakan makanan dalam jumlah banyak untuk anggota keluarga
Tabel 2. Analisis Regresi Logistik Ganda

\begin{tabular}{lccc}
\hline \multicolumn{1}{c}{ Nama Variabel } & $\mathrm{p}$ value & OR & $95 \% \mathrm{Cl}$ \\
\hline Tinggi Badan Ibu & 0.01 & 1.359 & $1.078-1.714$ \\
Tingkat Asupan Protein & 0.22 & 0.797 & $0.553-1.148$ \\
Tingkat Asupan Lemak & 0.03 & 1.296 & $1.023-1.643$ \\
Jumlah Anggota Rumah & 0.00 & 1.383 & $1.101-1.737$ \\
Tangga & & & \\
Sumber Air Minum & 0.01 & 1.358 & $1.062-1.736$ \\
\hline
\end{tabular}

yang banyak (Mamabolo et al. 2005). Pada umumnya ketersediaan makanan pada keluarga yang memiliki anggota banyak lebih sedikit jika dibandingkan dengan keluarga dengan anggota cukup sehingga rumah tangga yang memiliki jumlah anggota banyak lebih berisiko untuk mempunyai anak malnutrisi dibandingkan dengan rumah tangga yang memiliki jumlah anggota cukup (Tshwane University 2006).

\section{KESIMPULAN}

Prevalensi kejadian stunting pada balita usia 24-59 bulan di Provinsi Aceh, Sumatera Utara, Sumatera Selatan, dan Lampung adalah 44.1\%. Lebih dari seperempat balita memiliki berat lahir rendah dan lebih dari seperlima balita memiliki tingkat asupan energi, lemak, dan protein rendah. Lebih dari setengah tinggi badan ibu di keempat provinsi tergolong pendek dan keluarga berstatus ekonomi rendah; hampir setengah dari total keluarga memiliki jumlah anggota rumah tangga banyak; dan hampir sepertiga keluarga memiliki sumber air minum tidak terlindung.

Balita yang ibunya memiliki tinggi badan pendek, tingkat asupan lemak rendah, jumlah anggota keluarga banyak dan memiliki sumber air minum yang tidak terlindung berisiko mengalami stunting berurut-turut 1.36, 1.30, 1.38, dan 1.36 kali dibandingkan kelompok pembandingnya $(p<0.05)$. Faktor dominan yang berhubungan dengan kejadian stunting pada balita adalah jumlah anggota rumah tangga. Keluarga disarankan agar membatasi jumlah anak sesuai dengan program Keluarga Berencana (KB).

Dinas Kesehatan dan instansi-instansi terkait di empat provinsi sebaiknya meningkatkan pemberian informasi dan sosialisasi kepada masyarakat mengenai stunting misalnya melalui media booklet atau penyuluhan dan membuat kebijakan-kebijakan dalam 1000 hari kehidupan anak dalam rangka memperbaiki status gizi ibu hamil, ibu menyusui, dan anak balita.

\section{UCAPAN TERIMA KASIH}

Terima kasih disampaikan kepada Balitbangkes, Kemenkes RI yang telah mengizinkan penulis menggunakan data hasil survei Riskesdas 2010. 


\section{DAFTAR PUSTAKA}

Achadi LA .2012. Seribu Hari Pertama Kehidupan Anak. Disampaikan pada Seminar Sehari dalam Rangka Hari Gizi Nasional ke 60. FKM UI, Maret 2012 Depok.

Adewara SO, Labisi, \& Martine V. 2011. Use of Anthropometric Measures to Analyze How Sources of Water and Sanitation Affect Children's Health in Nigeria. Environment for Development Discussion Paper Series DP 1 1-0 2.

Assis AMO, Prado MS, \& Baretto ML et al. 2004. Childhood stunting in Northeas Brazil: the role Schistoma mansoi infection and inadequate dietary intake. Europian JCN, 58, 1022-1029.

[Kemenkes RI] Kementerian Kesehatan Republik Indonesia. 2011. Riset Kesehatan Dasar 2010. Kementerian Kesehatan RI, Jakarta.

Barker MD. 2008. Nutrition in The Womb. The Barker Foundation, USA.

Brinkman HJ, de Pee S, \& Sanogo I et al. 2010. High Food Prices and The Global Financial Crisis Have Reduced Access to Nutritious Food and Worsened Nutritional Status and Health. J. Nut, 140, 153S-161S.

Chang SM, Susan PW, Grantham-McG S, \& Christine AP. 2010. Early childhood stunting and later fine motor abilities. Developmental Medicine and Child Neurology, 52 (9), 831-836.

Hong R. 2007 Effect of economic inequality on chronic childhood under nutrition in Ghana. Public Health Nutrition, 10 (4), 371-378.

Hunt MJ. 2005. The potential impact of reducing global malnutrition on poverty reduction and economic development. Asia Pacific Journal Clinical Nutrition 14 (CD Supplement), 10-38.

Lee J, Houser RF, Must A, de Fulladolsa PP, \& Bermudez OI. 2010. Disentangling nutritional factors and household characteristics related to child stunting and maternal overweight in Guatemala. Economics and Human Biology, 8(2), 188-196.

Mamabolo RL et al. 2005. Prevalence and determinants of stunting and overweight in 3-yearsold black South African children residing in the Central Region of Limpopo Province, South Africa. Department of Medicine. University of Cape Town, Cape Town, South Africa.

Martorell R, Horta BL, \& Adair LS et al. Consortium on Health Oriented Research in Transitional Societies Group. 2010. Weight Gain in the First
Two Years of Life Is an Important Predictor of Schooling Outcomes in Pooled Analyses from Five Birth Cohorth from Low and Midle Income Countries. J. Nutr, 140, 348-354.

Merchant AT, Jones C, \& Kiure A et al. 2003. Water and Sanitation Associated with Improved Child Growth. Eur J Clin Nutr, 57(12), 1562-1568.

Simanjuntak B. 2011. Hubungan antara Berat Badan Lahir dan Faktor-Faktor Lainnya dengan Stunting (Pendek) pada Anak Usia 12-59 bulan di Sulawesi Tahun 2010 (Analisis Data Riskesdas 2010) [Tesis]. FKM UI, Depok.

Taguri AE, Ibrahim B, \& Salah MM et al. Risk Factor for Stunting Among Under-fives in Libya. 2008. Public Health Nutrition, 12(8), 1141- 1149.

Tshwane University of Technology and University of Limpopo. 2006. Stunting among young black children and the socio-economic and health status of their mothers/caregivers in poor areas of rural Limpopo and urban Gauteng-the NutriGro Study. SAJCN, 19(4).

[UNICEF] United Nation International Children's Emergency Fund. 1998. The State of the World's Children. Focus on Nutrition. http:// www.unicef.org/sowc98/silent4.htm (diakses 9 Juli 2012).

[UNICEF] United Nation International Children's Emergency Fund. 2009. Annual Report 2009. UNICEF Division Communication, New York, USA.

Varela-S M, Azcrra H, \& Dickinson F et al.2008. Influence of maternal stature, pregnancy age, and infant birth weight on growth during childhood in Yucatan. Mexico: a test of the intergenerational effects hypothesis. Am J Hum Biol, 21(5), 657-663.

Victora GC, Linda A, \& Caroline F et al. 2008. Maternal and child undernutrition: consequences for adult health and human capital. Lancet, 371, 340-357.

Xiaoli W, Beng H, \& Sufang G et al. 2009. Stunting and overweight in the WHO child growth standard: malnutrition among children in poor area in China. Public Health Nutrition, 12(11), 1991-1998.

Yang XL, Ye RW, Zheng JC, \& Jin L et al. 2010. Analysis on influencing factors for stunting and underweight among children aged 3-6 years in 15 counties of Jiangsu and Zhejiang Provinces. Zhonghua Liu Xing Bing Xue Za Zhi, 506-509. 